Article

\title{
Sun, Sand, and ... Sustainability in Developing Countries from a Tourists' Perspective. The Case of Punta Cana
}

\author{
Gianluca Goffi ${ }^{1,2}\left(\mathbb{D}\right.$, Magdalena Cladera $^{3}(\mathbb{D})$ and Linda Osti ${ }^{1, *(D)}$ \\ 1 Faculty of Economics and Management, Free University of Bozen-Bolzano, 39031 Brunico, Italy; \\ gianluca.goffi@unibz.it or gianluca.goffi@uniurb.it \\ 2 Department of Economics, Society and Politics, University of Urbino "Carlo Bo", 61029 Urbino, Italy \\ 3 Department of Applied Economics, University of the Balearic Islands, 07122 Palma de Mallorca, Spain; \\ mcladera@uib.es \\ * Correspondence: linda.osti@unibz.it
}

Received: 1 April 2020; Accepted: 3 June 2020; Published: 10 June 2020

\begin{abstract}
Large-scale tourism represents one of the main causes of environmental problems faced by many seaside destinations in developing countries. A survey was carried out among tourists in Punta Cana, the Dominican Republic, one of the most visited coastal destinations worldwide. This study explores whether the destination is meeting tourists' demand for sustainable practices and whether the sustainable initiatives implemented, as perceived by tourists, have a role in explaining tourists' satisfaction. An importance-performance analysis and a principal component analysis, followed by an ordered logit model, were performed. Findings show that tourists' expectations in terms of sustainability are not adequately met and that environmental and socioeconomic sustainability are positively associated with tourists' satisfaction.
\end{abstract}

Keywords: sustainable tourism development; coastal destinations; developing countries; large-scale tourism; "sun and sand" package vacations; Punta Cana; the Dominican Republic; Caribbean

\section{Introduction}

"Sun and sand" tourism is one of the most popular travel activities [1] and a significant source of income for seaside destinations in developing countries [2]. Tourism was regarded as "the great hope" for less developed economies, being a source of foreign exchange earnings and employment and the most feasible option for economic development [3]. The easiest way for developing countries to increase tourism flows was to delegate tourism development and marketing to large multinational operators [4]. Assuming to have low requirements from customers and little regulatory pressure, large tour operators had few motivations to implement sustainable practices [5]. Curtin and Busby [6] argued that "because they operate under the 'economies of scale' principle, they attempt to maximize the number of tourists in a resort". As a result of large-scale tourism development, many coastal destinations in developing countries have been damaged [7]. Indeed, coastal areas are often the first environments to experience the detrimental impacts of large-scale tourism [8]. As documented by Torres-Bejarano et al. [9], the number of tourists is one of the main factors in explaining the degradation of marine and coastal ecosystems.

For such reason, tourism sustainability in coastal destinations in developing countries is receiving increasing attention from tourism researchers. Most of the studies consider the supply-side perspective [e.g., hotels, tour operators). However, as claimed by Andrades-Caldito et al. [10], a demand-side perspective is needed when it comes to assessing attributes of destination attractiveness. The novelty of this paper lies in analyzing the role of sustainability from the tourists' perspective. The conceptual 
approach was developed from existing tourism studies by including in the analysis a number of key items to define the sustainability of a vacation at a coastal destination. The resulting questionnaire was submitted to organized tourists in Punta Cana, the Dominican Republic (DR), a leading Caribbean coastal destination characterized by package tourism.

Punta Cana, as well as other seaside destinations in developing countries, once famous for heavenly beaches and marine biodiversity, has been caught in a loop in trying to attract as many low-priced coastal packaged tourists as possible, with the consequence of losing its uniqueness and environmental value. As argued by Miller [11], even though an explicit demand for sustainability has still to be proven, there is growing evidence that organized tourists are not inclined to return to unsustainable destinations.

In light of the above, this paper seeks to answer the following two research questions:

RQ1. Is Punta Cana meeting tourists' demand for sustainable practices?

RQ2. Is there a positive relationship between the sustainable practices implemented, as perceived by tourists, and satisfaction with the vacation?

An Importance-Performance Analysis (IPA) was carried out to find out whether the destination is meeting visitors' expectations in terms of sustainability. In order to understand whether the sustainable initiatives implemented, as perceived by tourists, have a role in explaining satisfaction with the vacation, first a Principal Component Analysis (PCA) was carried out to condense the large number of variables into a smaller set. Then, the relationship among the components resulting from the PCA and tourists' satisfaction was tested through an ordered logit model.

Punta Cana, being a typical example of a coastal destination in a developing country of the Caribbean, affected by several environmental problems due to rapid and uncontrolled tourism development, was chosen as an applied case. Pentelow and Scott [12] posited that the Caribbean is the most tourism-intensive area worldwide. The World Travel and Tourism Council (WTTC) [13] showed that the Caribbean is the area in the world with the highest tourism total contribution to GDP $(15.2 \%)$, to employment $(13.8 \%)$, to total capital investment $(12.9 \%)$, and to total exports $(19.8 \%)$. Notwithstanding, little and mostly outdated empirical work in international tourism journals has focused on tourism sustainability in the Caribbean [14-20].

Tourism has been a key sector for the well-being of Caribbean states [20,21]. Caribbean countries have focused on tourism as a primary economic development option [22] also due to the progressive reduction in the export of agricultural products [23]. The Caribbean received 30.6 million international visitors in 2017 [24], and tourism contributes $\$ 57.1$ billion towards the region's GDP, which represents 15.2\% of its total GDP [25]. According to the "Travel and Tourism Competitiveness Report" of the "World Economic Forum" (WEF), most Caribbean economies rely extensively on their famous beaches and still need to address tourism competitiveness gaps: The DR is a typical example [26]. Most of the tourist arrivals in the DR, which is by far the Caribbean's leading tourism country, are concentrated in Punta Cana. Punta Cana is listed among the most tourism-penetrated seaside destinations worldwide [27]. According to the "Euromonitor International's Top City Destinations Ranking", Punta Cana ranks 58th among the 100 most visited destinations worldwide [28].

\section{Theoretical Overview}

The notion of tourism sustainability derives from the concept of sustainable development, which was addressed for the first time in the publication "World Commission on Environment and Development" known as the "Bruntland Report" (World Commission on Environment and Development [29]. Aware of the environmental problems faced by several destinations worldwide, a number of researchers have tried to understand and analyze tourism at the destination level from a sustainability perspective. Several studies focused on the environmental side of sustainability [30,31]. Butler [32] stated that sustainability should not be reduced to environmental matters. As noted by Swarbrooke [33], sustainable tourism is "tourism which is economically viable but does not destroy the resources on which the future of tourism will depend, notably the physical environment and 
the social fabric of the host community". Crouch and Ritchie [34] argued that a destination should be environmentally, socially, and economically sustainable. The discussions about sustainability seem to converge towards the idea that it rests at least on the three interrelated elements above. For such reason, we included in our questionnaire variables related to the environmental, social, and economic dimensions.

In the past few years, a growing interest in the subject area of tourism sustainability in coastal destinations in developing countries has emerged. Applying a model of destination competitiveness [35,36] adapted from the conceptual model of Crouch and Ritchie [34], Goffi, Cucculelli, and Masiero [37] established the key role played by sustainability in fostering destination competitiveness in Rio de Janeiro and Salvador de Bahia, two leading coastal destinations in South America. Solís-Radilla et al. [38] showed the relevance of sustainability in the loyalty to Acapulco, a mature large-scale seaside destination in Mexico. Cortés-Jiménez et al. [2] demonstrated that international tourism exchange earnings have contributed considerably towards financing the imports of capital goods in Tunisia, a developing country largely characterized by large-scale coastal tourism. However, international tourism receipts cannot be considered as an effective engine of economic growth, because the country relies almost exclusively on "low-differentiated, mass market-oriented resort hotels dominated by a few European major tour operators" [2].

Lacking the necessary expertise, for many seaside destinations in developing countries the most feasible option to sell and market their tourism products was to leave their tourism activities in the hands of multinational operators. Tour operators have become a dominating force in the holiday market, reaching a high share of tourists [39]. The last decade was characterized by the growth of low cost airline companies, online travel agencies and tour operators, the expansion of the number of independent travelers [40], and an intense price competition [41]. The tough market conditions were not helpful in achieving more sustainability. When asked about the adoption of sustainability measures, some tour operators responded that they had other priorities, such as filling the seats on charter flights, and did not have enough time to think about sustainability [42,43]. As a result, tourism has created numerous environmental problems and the degradation of the natural heritage in large-scale coastal destinations in developing countries [44].

Several seaside destinations in developed countries have moved towards a more sustainable approach of tourism development. The Balearic Islands, one of the world's leading areas for seaside tourism and a destination with high environmental problems, reacted to the decline in tourism revenues by implementing sustainable development policies [1,45]. Also in the case of the Canary Islands, the adoption of sustainable practices was the main strategy to overcome stagnation in tourism flows [46]. Bardolet and Sheldon [47], analyzing the case of the Balearic Island and Hawaii, came to the same conclusions. On the Spanish Mediterranean coastline, there are numerous examples of maturing large-scale coastal destinations rejuvenating thanks to the implementation of sustainable practices [48,49]. Andersen et al. [50] considered Denmark a best practice example of sustainability in coastal tourism development, due to almost a century of laws and policies aimed at protecting coastal areas.

This is not yet happening in most of the coastal destinations in developing countries such as Punta Cana. Developed countries have benefited from more favorable conditions for the application of sustainable practices, such as more funds, a better expertise in development and planning issues, and more stable economic conditions [51].

For these reasons, the following hypothesis is proposed:

Hypothesis 1 (H1). Punta Cana is underperforming in meeting tourists' demand for sustainable practices.

As stated by Dolnicar, Crouch, and Long [52] "researchers still have only a limited understanding of what tourist behavior can be considered as sustainable". Environmental concerns have grown considerably in the last few years and are affecting tourists' needs and behaviors [53]. Cottrell et al. [54] 
demonstrated tourists' sensitivity towards sustainability initiatives. Yaw [20] claimed that tourists are becoming increasingly demanding and a major question is the environmental conservation of the destinations. Miller [11] showed that unless there is no clear evidence of organized tourists' demand for green products, they will not revisit unsustainable destinations. According to Alegre and Garau [55], "for sun and sand destinations, the estimated model reveals that negative situations tied in with overdevelopment, tourism congestion and the destination's environmental degradation are highly important in explaining tourists' intention not to return". Solís-Radilla et al. [38] showed that sustainability mediated by tourists' expectations and experiences influences their intention to return to and to recommend Acapulco as a tourist destination.

Hence, a second hypothesis is proposed:

Hypothesis 2 (H2). There is a positive relationship between sustainable practices implemented, as perceived by tourists, and visitors' satisfaction.

A survey on a large sample of tour operators worldwide showed that smaller tour operators specializing in nature and culture tourism are much more engaged in sustainability compared to generalist and larger tour operators [56]. "Some overland, medium-sized and large sized tour operators felt that huge consumer pressure would be needed before they made any changes on issues that they did not regard as being at the core of their business" [57]. Tourists are the actors providing the initial trigger for adopting sustainable initiatives [58]. The existence of a demand for sustainable tourism can induce a transformation of the tourism sector in coastal destinations in developing countries characterized by large-scale package tourism. For such reason, it is important to understand whether a relationship between sustainability and tourists' satisfaction exists.

\section{The Case Study}

The DR is by far the Caribbean's main tourist country. In 2017, more than 6 million international tourists visited the country (6.188 million), while their number did not exceed 1.8 million in 1995 [59]. In 2017, tourist arrivals grew by $3.8 \%$ compared to 2016 and by 50\% compared to 2010 (4.125 million) [59]. In 2017 , in the DR, the total contribution of tourism to GDP was more than 13,006 million dollars $(17.2 \%$ of GDP), tourism industry represented $15.9 \%$ of total employment, and visitor exports generated $38.7 \%$ of total exports [13].

The DR accounts for $23.8 \%$ of all tourist arrivals in the Caribbean, and it is by far the foremost country in terms of tourism arrivals, followed by Cuba (3.9 million) and Puerto Rico (3.7 million) [60]. The DR, with over 10 million inhabitants, is also the second-largest Caribbean nation after Cuba. The DR is a place with outstanding natural resources and unique characteristics. The leading travel guide publisher "Lonely Planet" has mentioned the DR among the best ten countries to visit in 2013; "The country has all the elements of a perfect vacation destination. With sun-drenched beaches, ecotourism, a rich culture of music and dance, influential art galleries and museums, and of course a warm and welcoming people, it's no surprise that the DR is about to see a new wave of visitors" [61]. The DR is one of the world's leading destination for seaside tourism. It ranks 7th in the Americas for the number of international tourist arrivals after "giants" such as the USA, Mexico, and Canada [60], receiving a number of international tourists similar to Argentina (6.7 million) and Brazil (6.5 million), countries that are 57 and 174 times larger than the DR, respectively. These numbers are indicative of the pressure exerted by tourism on the delicate eco-system of the DR.

Tourism development in the DR was fostered by the country's process of democratization and adoption of 'neo-liberal' reforms in the 1970s and 1980s [62]. The DR has been one of the main trade liberalizers in the Caribbean [63], and its tourism development has been controlled by foreign multinational companies, which have established first-class hotels and lodge facilities, mainly in the Punta Cana area. In the DR, a few destinations account for the majority of tourist arrivals, while other 
areas are hardly visited. Three fifths of the tourist flow (58.9\% of the visitors) in the DR is concentrated in Punta Cana [64].

Punta Cana is situated in the municipality of Higüey in La Altagracia Province, and it is the easternmost tip of the DR. Punta Cana proper is no more than a small settlement near the airport, but it is so important for tourism that the entire East Coast is referred to by this name, covering about $420,000 \mathrm{~m}^{2}$, with a 100-kilometre coastline and an estimated population of 100,000 people. The name Punta Cana derives from the cane palms in the area, meaning "tip of the white cane palms". Punta Cana has been a famous destination since the 1970s, and it has become a major attraction for organized tourists over the last two decades due to its idyllic white sand beaches and turquoise water. As of 2017, Punta Cana can count on more than 40 thousand hotel rooms [65] (in 1995, there were about 8 thousand hotel rooms) and, according to the CEO of the Punta Cana Group, there are plans to reach 50 thousand in the next few years [66], in a seemingly endless growth. In the last two decades, there has been an enormous growth in foreign-owned, luxury chain hotels aimed at attracting high-spending tourists. The growth of tourism flows and hotels is creating even more strain on the fragile local ecosystems.

Punta Cana is by far the destination generating most of the tourism revenues in the DR and among the most tourism-penetrated destinations worldwide [27]. With less than 100 thousand inhabitants, Punta Cana tops the list of the tourism destinations in Latin America with an estimated US\$2.7 billion visitor spending, followed by Buenos Aires and Mexico City (US\$2.3 billion) [67]. With 4.3 million tourists arrivals, Punta Cana ranks 2nd among the top cities in Latin America, after Cancun (6.3 million), followed by Santiago de Chile and Lima (2.6 million), Buenos Aires and Mexico City (2.4 million), and Rio de Janeiro (2.3 million) [28]. Punta Cana International Airport was constructed in 1984 and it is privately owned; now it is one of the busiest airports in Latin America [67]. Punta Cana received 1.428 million North American tourists, 565 thousand Canadians, and 489 thousand South Americans, 1.016 million Europeans; tourist arrivals in Punta Cana grew by a further 5.6\% in 2017 compared to 2016 [64]. Punta Cana had a 82.8\% hotel occupancy rate in 2017 (compared to the $64 \%$ of Puerto Plata), reaching the peak in July (93\%), followed by January and February (90\%) [68].

\section{Methods}

For the purpose of this study, a survey instrument was created. The items used in the questionnaire were based on the papers exposed in the above literature review dealing with the main pillars of the sustainability of a vacation-environmental, sociocultural, and economic-translated into several items to assess the sustainable initiatives implemented in Punta Cana. The questionnaire was pretested on fifteen tourism practitioners and researchers; subsequently, a pilot test was carried out on 30 tourists. The questionnaire was translated into five languages; Spanish, Italian, English, Dutch, and French. The respondents were asked for their email address and to complete the online questionnaire when back home, in order to obtain quality responses at the end of their vacation. Altogether, 1450 surveys were mailed to organized tourists, and 307 usable surveys were returned.

Following the methodology applied in Sörensson and Von Friedrichs' work [69], tourists were asked to evaluate the identified sustainable initiatives and the importance of some attributes related to sustainability of the vacation on a 5-point Likert scale. Each of the importance features had a performance counterpart that tourists had to assess in the list of identified sustainable initiatives implemented in Punta Cana. They were also asked to rate their satisfaction with the vacation on a 5-point Likert scale.

To answer RQ1 ("Is Punta Cana meeting tourists' demand for sustainable practices?"), an IPA was performed. IPA has been used in a variety of applications, being an "easily-applied technique for measuring attribute importance and performance" [70]. As recommended by Azzopardi and Nash [71], instead of the classic "four quadrants" methodology, a diagonal, "iso-rating line"-that gives information regarding the satisfaction/dissatisfaction situation for each attribute whatever the quadrant position is-was introduced for the current analysis (Figure 1). According to Sever [72], the iso-rating line "is arguably a more suitable method for identifying areas of concern, compared 
to the subjective thresholds-selection method, as it directly focuses on differences in satisfaction and importance ratings".

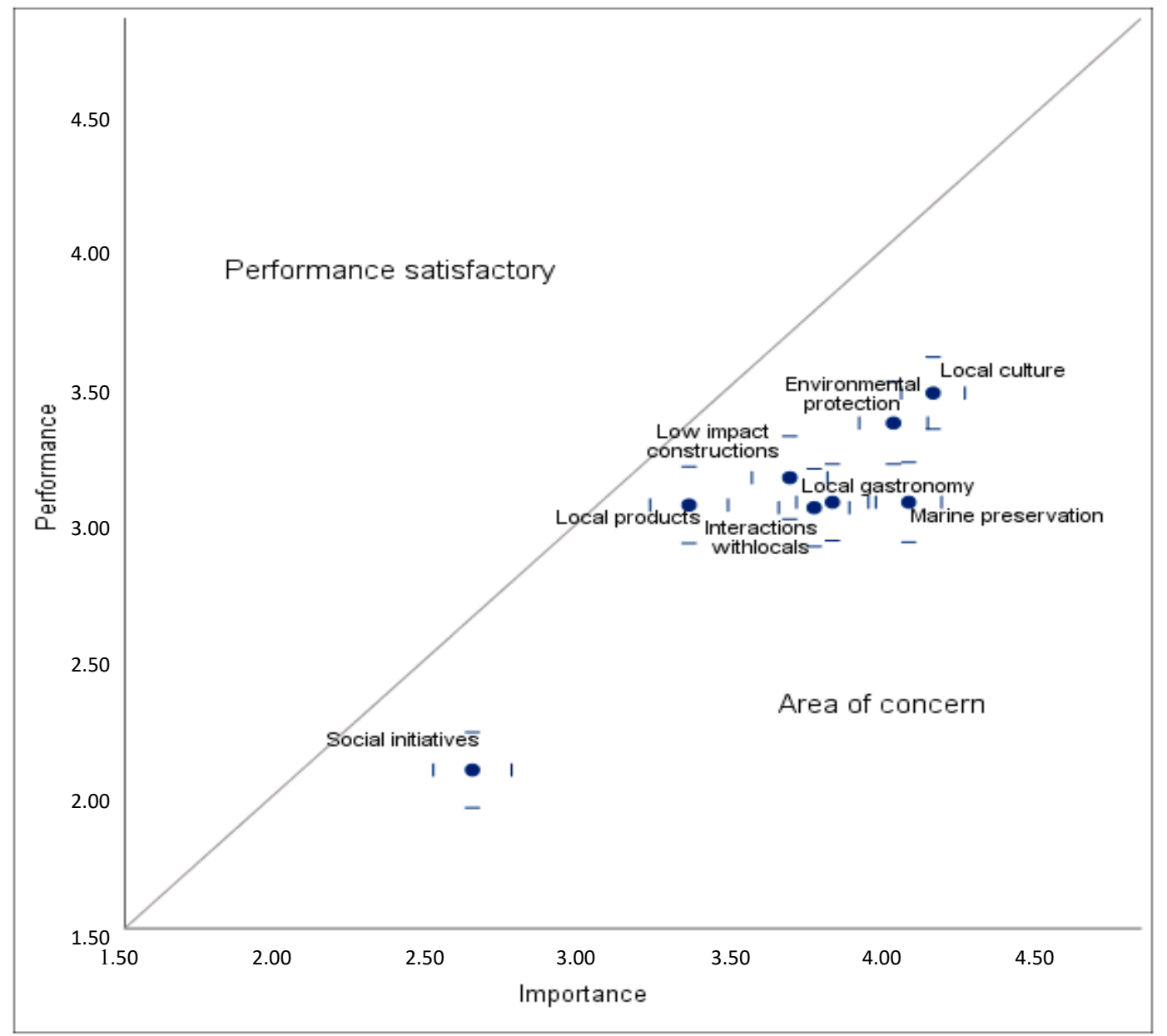

Figure 1. Importance-Performance Analysis.

To answer RQ2 ("Is there a positive relationship between sustainability and tourists' satisfaction?"), an ordered logit model was estimated for overall satisfaction. The components obtained from the previous PCA analysis were included in the regression as explanatory variables. In addition, tourists' socio-demographic and trip characteristics were also used as independent variables (sex, age, education, country of origin, size of the travel party, number of organized trips in the last ten years, number of previous visits to the DR, and number of previous trips with the tour operator). The variables that were not statistically significant were removed and the final model was re-estimated.

\section{Results}

As reported in Table 1, the 307 respondents have a heterogeneous profile with about half of them (52\%) being women, $41 \%$ holding university education (and $49 \%$ non-university education), mostly travelling with friends or partners, and mainly aged between 30 and 60 years.

To answer RQ1, an IPA was performed. The importance-performance scores are shown in Table 2. All the importance-performance spots are statistically significant.

As emerges from Figure 1, all the variables are well below the iso-rating line, in the "area of concern", indicating that sustainability is a critical factor that needs to be enhanced in order to meet tourists' expectations, thus confirming the first hypothesis of the study. Tourists consider marine preservation, environmental preservation and local culture as the most important across all of the 
indicators, scoring an importance value above ' 4 ', with overall destination performance judged as not satisfactory (below ' $3.5^{\prime}$ ). High levels of importance, above '3.7', are also attributed to local gastronomy, interaction with locals, and to low impact constructions, with destination performance also considered as not satisfactory (below '3.2').

Table 1. Sample's descriptive statistics.

\begin{tabular}{|c|c|c|c|}
\hline Variable & $\%$ & Variable & $\%$ \\
\hline Sex & & $\begin{array}{l}\text { Country of } \\
\text { residence }\end{array}$ & \\
\hline Male & 47.7 & Europe & 79.9 \\
\hline Female & 52.3 & America & 14.8 \\
\hline Age & & Asia & 3.3 \\
\hline $18-29$ & 10.7 & Oceania & 2.0 \\
\hline $30-44$ & 48.7 & Travel companion & \\
\hline $45-59$ & 34.8 & Alone & 3.0 \\
\hline 60 and over & 5.8 & Friends & 31.3 \\
\hline Education & & Partner & 48.0 \\
\hline $\begin{array}{l}\text { Non-university } \\
\text { education }\end{array}$ & 49.3 & Family & 10.5 \\
\hline $\begin{array}{l}\text { University } \\
\text { education }\end{array}$ & 40.7 & Other & 7.2 \\
\hline
\end{tabular}

Table 2. Importance-performance scores.

\begin{tabular}{cccccc}
\hline & Importance & Performance & Difference & T-Value & Significance \\
\hline & (rank) & (rank) & & & \\
\hline Marine preservation & 4.09 & 3.06 & 1.03 & 6.816 & 0.000 \\
Local gastronomy & 3.82 & 3.06 & 0.76 & 9.200 & 0.000 \\
Interactions with locals & 3.76 & 3.04 & 0.72 & 9.027 & 0.000 \\
Local culture & 4.15 & 3.46 & 0.69 & 9.600 & 0.000 \\
Environmental & 4.04 & 3.35 & 0.69 & 8.337 & 0.000 \\
protection & 2.64 & 2.09 & 0.55 & 7.246 & 0.000 \\
Social initiatives & 3.70 & 3.15 & 0.55 & 6.438 & 0.000 \\
Low impact & 3.35 & 3.05 & 0.30 & 3.294 & 0.001 \\
constructions & & & & &
\end{tabular}

Results of the IPA analysis indicate that Punta Cana should focus on improving marine preservation, which scored the higher difference between importance and destination performance. This issue appears to represent the first area of intervention for the local tourism policy makers in order to meet tourists' expectations. A further priority area of intervention is environmental protection. IPA results also suggest that not only marine and environmental protection measures should be improved, but also that the linkages with local gastronomy and culture, and the interactions with the local community should be enhanced. In other words, the beach resort sites should not be self-sufficient complexes isolated from the local community and businesses. Local residents, culture, and activities are part of the tourism product that tourists want to experience. Further areas to improve are the environmental impact of constructions, the social initiatives, and the offer of local products.

To answer RQ2, a PCA and an ordered logit model were performed. "Bartlett's test of sphericity" and the "Kaiser-Meyer-Olkin" (KMO) statistic were calculated to detect if the information provided by the initial variables can be summarized in a few factors [73]. The value of the KMO is equal to 0.913, 
which is considered very adequate, and "Barlett's test of sphericity" yields a significant Chi-Square value $(\chi=1750.24$, Sig. 0.000). This confirms the appropriateness of the PCA for this study. Cronbach's Alpha was also calculated for each component, confirming the reliability of the variables, as showed in Table 3

Table 3. Principal Component Analysis (PCA) of sustainability assessment.

\begin{tabular}{ccccc}
\hline Components & Loadings & Variance (\%) & Communalities & Cronbach's Alpha \\
\hline C1. Environmental Sustainability & & $\mathbf{2 8 . 3 3 8}$ & & $\mathbf{0 . 8 6 1}$ \\
\hline Ecological building materials & 0.820 & & 0.718 & \\
Preservation of native vegetation & 0.789 & & 0.634 & \\
Low-impact constructions & 0.728 & & 0.532 & \\
Preservation of natural reserves & 0.708 & & 0.587 & \\
Eco-friendly local transports & 0.668 & & 0.579 & \\
Environmental information & 0.576 & & & \\
\hline C2. Socioeconomic Sustainability & & $\mathbf{2 7 . 1 6 0}$ & 0.584 \\
\hline Promotion of local gastronomy & 0.760 & & 0.582 & \\
Promotion of local products & 0.756 & & 0.503 & \\
Promotion of local tours & 0.709 & & 0.566 & \\
Interactions with locals & 0.657 & & 0.557 & \\
Cultural information & 0.645 & & 0.441 & \\
Preservation of local culture & 0.628 & & 0.334 & \\
Promotion of local initiatives & 0.525 & & \\
Promotion of local businesses & 0.491 & & \\
\hline KMO Measure of Sampling Adequacy & 0.913 & & \\
Bartlett's test of sphericity & 1750.24 & & \\
& 0.000 & & \\
\hline
\end{tabular}

The PCA revealed two components, explaining $55.5 \%$ of the variance. The variables incorporated into each component are displayed in Table 3 . The first component explains $28.3 \%$ of the variation. This component covers the concept of "environmental sustainability" and is associated with environmental practices, including preservation of native vegetation and natural reserves, low-impact of constructions and buildings, environmental information, and eco-friendly transports. The second component (27.2\%) refers to "socioeconomic sustainability" and groups items such as the promotion of local products, gastronomy, tours, businesses and initiatives, the preservation of local culture, cultural information, and interactions with locals.

Table 4 summarizes the results of the effects of the PCA components on the dependent variable. The results of the regression analysis show that both components- "environmental sustainability" and "socio-economic sustainability" —are positively associated at a significant level to tourists' satisfaction, corroborating the existence of a positive relationship between the sustainable initiatives implemented, as perceived by tourists, and satisfaction with the vacation, thus confirming the second hypothesis of the study.

Table 4. Ordered logit estimations for the effects of sustainability components on tourist satisfaction.

\begin{tabular}{cccc}
\hline & Coefficient & Standard Error & Significance \\
\hline C1. Environmental Sustainability & 0.472 & 0.124 & 0.000 \\
C2. Socioeconomic Sustainability & 0.458 & 0.126 & 0.000 \\
Model fitting (Sig.) & $517.308(0.000)$ & & \\
Goodness of Fit & & & \\
Pearson (Sig.) & $570.321(0.055)$ & & \\
Deviance (Sig.) & $517.308(0.500)$ & & \\
Nagelkerke Pseudo-R & 0.254 & & \\
Test of parallel lines (Sig.) & $493.009(0.445)$ & & \\
Number of observations & 272 & & \\
\hline
\end{tabular}




\section{Discussion}

This study explores whether Punta Cana is meeting visitors' expectations in terms of sustainability and whether the sustainable initiatives implemented, as perceived by tourists, have a role in explaining their satisfaction with the vacation.

Findings show that Punta Cana is not adequately meeting tourists' demand for sustainable practices. As shown by the IPA analysis, the importance level of all attributes related to sustainability is greater than their performance level. In other words, all sustainability attributes are issues on which the destination should strongly concentrate and invest. More importantly, however, this paper demonstrates the influence of sustainability initiatives in explaining tourists' satisfaction.

This study shows the key relevance of environmental issues, which strongly emerges in the significance of the component "environmental sustainability" in explaining tourists' satisfaction. The DR has been characterized by a form of tourism development harmful to the island's delicate ecosystems [27]. The local tourism industry faces environmental critical problems, such as underground and coastal water pollution, congestion of beaches, deforestation, overuse of resources, overexploitation of aquifers, degradation of ecosystems, and coral reef erosion [74-76]. In the last few years, nature has been gradually replaced by tourism constructions; luxurious resort complexes, and cities planned for foreign ownership (such as, for example, Cap Cana) have been built in Punta Cana [77]. Empirical evidence shows that the lack of attention to environmental protection is not only detrimental to the local ecosystem, but can also have a negative impact on tourists' satisfaction. Environmental stress threatens the key resource on which the destination depends; its attractive environment.

Aware of the environmental problems faced by the coastal destinations in the DR, the government has recently decided to move towards a more sustainable policy framework. In May 2019, in Punta Cana, the "Roadmap for Low Carbon and Resource Efficient Accommodation in the Dominican Republic" [78] was launched jointly with the United Nations Environment Programme. The roadmap identifies five objectives for accommodation facilities in the country; specifically, reducing greenhouse gas emissions, non-renewable energy use, food waste; eliminating single-use plastics; adopting sustainability certifications. The hope is that the implementation of the program will lead to substantial improvements in the sustainability performance of the local tourism industry.

Results show the role of the component "socioeconomic sustainability" in explaining tourists' satisfaction. This component contains several variables related to local economic linkages, such as promotion of local gastronomy, tours, products, businesses and initiatives. This in turn means that tourism linkages with the local economy should be fostered not only to improve local well-being, but also to increase tourists' satisfaction. Tourism is the key sector of the country's economy. Its contribution to the GDP amounts to $18 \%$, generating about $20 \%$ of jobs in the country (direct and indirect), and gross income exceeds 4 billion dollars [79]. Nevertheless, the population in the DR has benefited only to a small extent from the growth of this sector. In developing countries, a large share of the economic benefits of tourism are lost due to high leakages of tourism revenues [80-82].

The history of the DR is characterized, as it is elsewhere in the Caribbean region, by colonial maladministration and plantation slavery [83], a legacy that seems to continue to inhibit economic growth. The DR has experienced growing debt problems, unemployment, and high inflation; according to the World Bank data, more than a third of the country's total population is living in poverty [84] (almost 20\% in extreme poverty), with a shortage of basic food and sanitary and health problems. In rural areas, half of the population is constituted by poor people [85]. The fast development of tourism in Punta Cana has induced many people to move to the coastal region of Punta Cana in search of formal or informal job opportunities in tourism, but has also led to several endemic urbanization problems. Workers migrated to the surrounding areas, with shantytown areas housing hundreds of Dominican and Haitian tourism workers. Such unplanned and chaotic growth has resulted in several problems in environmental and public health management, such as a lack of sanitation facilities and solid waste disposal or sewerage systems, and poor road conditions and public 
transport system [74-76]. Leon [86] showed that seaside tourism had a positive impact on rural livings standards in the DR, improving well-being and raising various families from poverty.

These outcomes underscore the importance of adopting a wider strategy to support local tourism businesses. The focus of tourism plans should shift from providing low-cost workers in response to the tourism industry's request, to local empowerment and human resource capacity building [87]. Greater attention should be paid to local economic linkages in order to maximize economic impacts on the local economy and to meet tourists' expectations.

Our findings contribute to the existing debate on the sustainability of coastal destinations in developing countries by showing a demand for sustainable tourism. The results are consistent with the evidence that if coastal destinations in developing countries will not adopt a more sustainable structure of tourism development they could lose most of their appeal. Indeed, as claimed by Aguiló, Alegre, and Sard [45], "the model's persistence, in the long term, must be based on the adaptation of the sun-and-sand tourism model within the framework of sustainable development." In light of the observed results, our findings suggest that policy legislation and regulation in seaside destinations in developing countries should be directed at stimulating tour operators' investment in sustainable practices. From the environmental side, the implementation of environmental certifications, together with other initiatives of environmental management, may represent an effective way of enhancing sustainable outcomes [88].

With the present paper, we have aimed to advance the existing literature on tourism sustainability by gleaning new insights into the positive effects of sustainability on tourists' satisfaction in coastal destinations in developing countries; however, our study is not free from limitations. One limitation of this study is represented by the number of respondents, which, for the type of analysis employed, can be considered relatively small. Thus, future studies are encouraged to utilize a larger sample to confirm the relationships found in this work. Despite a relatively narrow sample size, these results should be considered as a first step to understanding the importance of sustainability in coastal destinations in developing countries from a demand point of view. A further possible limitation might be represented by the ability of tourists to assess some of the variables related to sustainability. The paper was aimed at analyzing visitors' perceptions towards sustainability, which may differ from the actual level of sustainability of the destination. In fact, sustainability discourses are mainly concentrated on the supply side, not adequately considering the influence of the demand side [6]. Therefore, this study can be considered as an initial attempt to investigate the sustainability initiatives implemented in a coastal destination from a demand perspective. To enhance the generalizability of results from this study, replication for further coastal destinations in developing countries is encouraged.

Author Contributions: Conceptualization, G.G.; data curation, G.G.; formal analysis, M.C.; investigation, G.G.; methodology, M.C.; project administration, G.G.; resources, G.G. and L.O.; supervision, L.O.; writing - original draft, G.G.; writing-review \& editing, G.G. and L.O. All authors have read and agreed to the published version of the manuscript.

Funding: This work was supported by the Open Access Publishing Fund of the Free University of Bozen-Bolzano.

Conflicts of Interest: The authors declare no conflict of interest.

\section{References}

1. Dodds, R. Sustainable Tourism and Policy Implementation: Lessons from the Case of Calviá, Spain. Curr. Issues Tour. 2007, 10, 296-322. [CrossRef]

2. Cortés-Jiménez, I.; Nowak, J.-J.; Sahli, M. Mass Beach Tourism and Economic Growth: Lessons from Tunisia. Tour. Econ. 2011, 17, 531-547. [CrossRef]

3. Tosun, C. Challenges of sustainable tourism development in the developing word: The case of Turkey. Tour. Manag. 2001, 22, 289-303. [CrossRef]

4. Yfantidou, G.; Matarazzo, M. The Future of Sustainable Tourism in Developing Countries. Sustain. Dev. 2016, 25, 459-466. [CrossRef] 
5. Budeanu, A. Corrigendum to "Environmental supply chain management in tourism: The case of large tour operators." [Journal of Cleaner Production Volume. 17 Issue 16: 1385-1392]. J. Clean. Prod. 2011, 19, 1777. [CrossRef]

6. Curtin, S.; Busby, G. Sustainable destination development: The tour operator perspective. Int. J. Tour. Res. 1999, 1, 135-147. [CrossRef]

7. El Mrini, A.; Anthony, E.; Maanan, M.; Taaouati, M.; Nachite, D. Beach-dune degradation in a Mediterranean context of strong development pressures, and the missing integrated management perspective. Ocean. Coast. Manag. 2012, 69, 299-306. [CrossRef]

8. Baldwin, J. Tourism development, wetland degradation and beach erosion in Antigua, West Indies. Tour. Geogr. 2000, 2, 193-218. [CrossRef]

9. Torres-Bejarano, F.; Márquez, L.C.G.; Diaz-Solano, B.H.; Torregroza-Espinosa, A.C.; Cantero-Rodelo, R. Effects of beach tourists on bathing water and sand quality at Puerto Velero, Colombia. Environ. Dev. Sustain. 2016, 20, 255-269. [CrossRef]

10. Andrades-Caldito, L.A.; Rivero, M.S.; Fernández, J.I.P. Tourism Destination Competitiveness from a Demand Point of View: An Empirical Analysis for Andalusia. Tour. Anal. 2014, 19, 425-440. [CrossRef]

11. Miller, G.A. Consumerism in Sustainable Tourism: A Survey of UK Consumers. J. Sustain. Tour. 2003, 11, 17-39. [CrossRef]

12. Pentelow, L.; Scott, D. Aviation's inclusion in international climate policy regimes: Implications for the Caribbean tourism industry. J. Air Transp. Manag. 2011, 17, 199-205. [CrossRef]

13. WTTC. Travel \& Tourism Economic Impact 2018. Dominican Republic; World Travel \& Tourism Council: London, UK, 2018.

14. Hills, T.L.; Lundgren, J. The impact of tourism in the Caribbean. Ann. Tour. Res. 1977, 4, 248-267. [CrossRef]

15. McElroy, J.L.; De Albuquerque, K. Tourism penetration index in small Caribbean islands. Ann. Tour. Res. 1998, 25, 145-168. [CrossRef]

16. Belisle, F.J.; Hoy, D.R. The perceived impact of tourism by residents a case study in Santa Marta, Colombia. Ann. Tour. Res. 1980, 7, 83-101. [CrossRef]

17. Holder, J.S. Pattern and impact of tourism on the environment of the Caribbean. Tour. Manag. 1988, 9, 119-127. [CrossRef]

18. Weaver, D.B. Alternative to mass tourism in Dominica. Ann. Tour. Res. 1991, 18, 414-432. [CrossRef]

19. De Albuquerque, K.; McElroy, J.L. Caribbean small-island tourism styles and sustainable strategies. Environ. Manag. 1992, 16, 619-632. [CrossRef]

20. Yaw, F., Jr. Cleaner technologies for sustainable tourism: Caribbean case studies. J. Clean. Prod. 2005, 13, 117-134. [CrossRef]

21. McLeod, M.; Lewis, E.H.; Spencer, A. Re-inventing, revolutionizing and transforming Caribbean tourism: Multi-country regional institutions and a research agenda. J. Destin. Mark. Manag. 2017, 6, 1-4. [CrossRef]

22. Seraphin, H.; Gowreesunkar, V.; Roselé-Chim, P.; Duplan, Y.J.J.; Korstanje, M. Tourism planning and innovation: The Caribbean under the spotlight. J. Destin. Mark. Manag. 2018, 9, 384-388. [CrossRef]

23. Ahmed, B. The impact of globalization on the Caribbean sugar and banana industries. In The Society for Caribbean Studies Conference Papers; Courtman, S., Ed.; The University of Nottingham: Nottingham, UK, 2001; Volume 2.

24. CTO. CTO Annual Statistical Report 2018; Caribbean Tourism Organization: Warrens St Michael, Barbados, 2018.

25. WTTC. Travel \& Tourism Economic Impact 2018 Caribbean; World Travel \& Tourism Council: London, UK, 2018.

26. WEF. The Travel \& Tourism Competitiveness Report 2017; World Economic Forum: Geneva, Switzerland, 2017.

27. Padilla, A.; McElroy, J.L. The Tourism Penetration Index in Large Islands: The Case of the Dominican Republic. J. Sustain. Tour. 2005, 13, 353-372. [CrossRef]

28. Euromonitor International. Top 100 City Destinations Ranking, WTM 2018 ed.; Euromonitor International: London, UK, 2018.

29. WCED. Report of the World Commission on Environment and Development: Our Common Future; Oxford University Press: Oxford, UK, 1987.

30. Mihalič, T. Environmental management of a tourist destination. Tour. Manag. 2000, 21, 65-78. [CrossRef]

31. Hassan, S.S. Determinants of Market Competitiveness in an Environmentally Sustainable Tourism Industry. J. Travel Res. 2000, 38, 239-245. [CrossRef] 
32. Butler, R.W. Sustainable tourism: A state-of-the-art review. Tour. Geogr. 1999, 1, 7-25. [CrossRef]

33. Swarbrooke, J. Sustainable Tourism Management; CAB International: Wallingford, UK, 1999.

34. Crouch, G.I.; Ritchie, J. Tourism, Competitiveness, and Societal Prosperity. J. Bus. Res. 1999, 44, 137-152. [CrossRef]

35. Goffi, G.; Cucculelli, M. Components of destination competitiveness. The case of small tourism destinations in Italy. Int. J. Tour. Policy 2014, 5, 296. [CrossRef]

36. Goffi, G.; Cucculelli, M. Explaining tourism competitiveness in small and medium destinations: The Italian case. Curr. Issues Tour. 2018, 22, 2109-2139. [CrossRef]

37. Goffi, G.; Cucculelli, M.; Masiero, L. Fostering tourism destination competitiveness in developing countries: The role of sustainability. J. Clean. Prod. 2019, 209, 101-115. [CrossRef]

38. Solís-Radilla, M.M.; Hernández-Lobato, L.; Callarisa-Fiol, L.J.; Pastor-Durán, H.T. The Importance of Sustainability in the Loyalty to a Tourist Destination through the Management of Expectations and Experiences. Sustainability 2019, 11, 4132. [CrossRef]

39. Schwartz, K.; Tapper, R.; Font, X.A. Sustainable Supply Chain Management Framework for Tour Operators. J. Sustain. Tour. 2008, 16, 298-314. [CrossRef]

40. Picazo, P.; Moreno-Gil, S. Tour operators' marketing strategies and their impact on prices of sun and beach package holidays. J. Hosp. Tour. Manag. 2018, 35, 17-28. [CrossRef]

41. Falzon, J. The price competitive position of Mediterranean countries in tourism: Evidence from the Thomson brochure. Tour. Manag. 2012, 33, 1080-1092. [CrossRef]

42. Forsyth, T. Business attitudes to sustainable tourism. J. Sustain. Tourism 1995, 3, 210-231. [CrossRef]

43. Van der Duim, R.; Van Marwijk, R. The implementation of an environmental management system for Dutch tour operators: An actor-network perspective. J. Sustain. Tourism 2009, 14, 449-472. [CrossRef]

44. Shaalan, I.M. Sustainable tourism development in the Red Sea of Egypt threats and opportunities. J. Clean. Prod. 2005, 13, 83-87. [CrossRef]

45. Aguiló, E.; Alegre, J.; Sard, M. The persistence of the sun and sand tourism model. Tour. Manag. 2005, 26, 219-231. [CrossRef]

46. Oreja Rodríguez, J.R.; Parra-López, E.; Yanes-Estévez, V. The sustainability of island destinations: Tourism area life cycle and teleological perspectives. The case of Tenerife. Tour. Manag. 2008, 29, 53-65. [CrossRef]

47. Bardolet, E.; Sheldon, P.J. Tourism in Archipelagos Hawai'i and the Balearics. Ann. Tour. Res. 2008, 35, 900-923. [CrossRef]

48. Blancas, F.J.; González, M.; Oyola, M.L.; Perez, F. The assessment of sustainable tourism: Application to Spanish coastal destinations. Ecol. Indic. 2010, 10, 484-492. [CrossRef]

49. Ivars-Baidal, J.A.; Sánchez, I.R.; Rebollo, J.F.V. The evolution of mass tourism destinations: New approaches beyond deterministic models in Benidorm (Spain). Tour. Manag. 2013, 34, 184-195. [CrossRef]

50. Andersen, I.M.V.; Blichfeldt, B.S.; Liburd, J.J. Sustainability in coastal tourism development: An example from Denmark. Curr. Issues Tour. 2016, 21, 1329-1336. [CrossRef]

51. Helmy, E. Towards Integration of Sustainability into Tourism Planning in Developing Countries: Egypt as a Case Study. Curr. Issues Tour. 2004, 7, 478-501. [CrossRef]

52. Dolnicar, S.; Crouch, G.I.; Long, P. Environment-friendly Tourists: What Do We Really Know about Them? J. Sustain. Tour. 2008, 16, 197-210. [CrossRef]

53. Bergin-Seers, S.; Mair, J. Emerging green tourists in Australia: Their behaviours and attitudes. Tour. Hosp. Res. 2009, 9, 109-119. [CrossRef]

54. Cottrell, S.; Van Der Duim, R.; Ankersmid, P.; Kelder, L. Measuring the Sustainability of Tourism in Manuel Antonio and Texel: A Tourist Perspective. J. Sustain. Tour. 2004, 12, 409-431. [CrossRef]

55. Alegre, J.; Garau, J. Tourist satisfaction and dissatisfaction. Ann. Tour. Res. 2010, 37, 52-73. [CrossRef]

56. Goffi, G.; Masiero, L.; Pencarelli, T. Rethinking sustainability in the tour-operating industry: Worldwide survey of current attitudes and behaviors. J. Clean. Prod. 2018, 183, 172-182. [CrossRef]

57. Tapper, R. Tourism and socio-economic development: UK tour operators' business approaches in the context of the new international agenda. Int. J. Tour. Res. 2001, 3, 351-366. [CrossRef]

58. Goffi, G.; Cladera, M.; Pencarelli, T. Does sustainability matter to package tourists? The case of large-scale coastal tourism. Int. J. Tour. Res. 2019, 21, 544-559. [CrossRef]

59. The World Bank Data. Available online: http://data.worldbank.org/indicator/ST.INT.ARVL (accessed on 6 September 2019). 
60. UNWTO. Tourism Highlights: 2018 Edition; World Tourism Organization (UNWTO): Madrid, Spain, 2018.

61. The Dominican Republic Official Tourism Website. Available online: https://www.godominicanrepublic. com/news-posts/archived/lonley-planet-names-dominican-republic-best-in-travel-for-2013/ (accessed on 24 July 2019).

62. Mitchell, K. Democratisation, External Exposure and State Food Distribution in The Dominican Republic. Bull. Lat. Am. Res. 2009, 28, 204-226. [CrossRef]

63. Santos-Paulino, A.U. The Dominican Republic Trade Policy Review 2008. World Econ. 2010, 33, $1414-1429$. [CrossRef]

64. Banco Central de la República Dominicana. Estadísticas Turísticas 2017; Abril: Santo Domingo, Dominican Republic, 2018.

65. Diario turistico de la Republica Dominicana arecoa.com. Available online: www.arecoa.com/destinos/2018/ 09/07/peso-punta-cana-12-anos-atrayendo-mas-del-50-turistas-rd (accessed on 6 September 2019).

66. Diario turistico de la Republica Dominicana arecoa.com. Available online: www.arecoa.com/ hoteles/2016/04/21/rainieri-visualizo-a-punta-cana-en-10-anos-con-mas-de-50000-habitaciones (accessed on 6 September 2019).

67. Hedrick-Wong, Y.; Choong, D. MasterCard 2015 Global Destination Cities Index. Tracking Global Growth: 2009-2015; Mastercard: New York, NY, USA, 2016.

68. Asonahores. Boletin Estatistico Volume 186; Asociación de Hoteles y Turismo de la República Dominicana: Santo Domingo, Dominican Republic, 2018.

69. Sörensson, A.; von Friedrichs, Y. An importance-performance analysis of sustainable tourism: A comparison between international and national tourists. J. Destin. Mark. Manag. 2013, 2, 14-21. [CrossRef]

70. Martilla, J.A.; James, J.C. Importance-Performance Analysis. J. Mark. 1977, 41, 77. [CrossRef]

71. Azzopardi, E.; Nash, R. A critical evaluation of importance-performance analysis. Tour. Manag. 2013, 35, 222-233. [CrossRef]

72. Sever, I. Importance-performance analysis: A valid management tool? Tour. Manag. 2015, 48, 43-53. [CrossRef]

73. Hair, J.F., Jr.; Anderson, R.E.; Tatham, R.L.; Black, W.C. Multivariate Data Analysis, 3rd ed.; Macmillan Publishing Company: New York, NY, USA, 1995.

74. Ruta, G. Coastal Zones Management and Tourism in the Dominican Republic; World Bank: Washington, DC, USA, 2003.

75. Wielgus, J.; Cooper, E.; Torres, R.; Burke, L. Coastal Capital: Dominican Republic. Case Studies on the Economic Value of Coastal Ecosystems in the Dominican Republic; Working Paper; World Resources Institute: Washington, DC, USA, 2010.

76. Redwood, J. Dominican Republic Environmental and Social Safeguards Issues Paper: Upstreaming Environmental and Social Risk Management; Inter-American Development Bank: Washington, DC, USA, 2012.

77. Punta Cana International Airport. Available online: www.puntacanainternationalairport.com (accessed on 6 September 2019).

78. UNEP. Roadmap for Low Carbon and Resource Efficient Accommodation in the Dominican Republic; United Nations Environment Programme: Paris, France, 2019.

79. Constanzo, P. Dominican Republic Clusters: Pillars of Development. In Tourism in Latin America: Cases of, Success; Panosso Netto, A., Godoi Trigo, L.G., Eds.; Springer: Berlin/Heidelberg, Germany, 2014.

80. Telfer, D.J.; Wall, G. Strengthening backward economic linkages: Local food purchasing by three Indonesian hotels. Tour. Geogr. 2000, 2, 421-447. [CrossRef]

81. Sandbrook, C.G. Putting leakage in its place: The significance of retained tourism revenue in the local context in Rural Uganda. J. Int. Dev. 2008, 22, 124-136. [CrossRef]

82. Page, S.; Connell, J. Tourism: A modern synthesis; Cengage Learning EMEA: London, UK, 2006.

83. Minto-Coy, I.; Berman, E. Public Administration and Policy in the Caribbean. In State and Local Pension Fund Management; CRC Press, Taylor and Francis Group: Boca Raton, FL, USA, 2015; pp. 1-30.

84. CapCana Republica Dominicana. Available online: http://capcana.com (accessed on 6 September 2019).

85. The International Fund for Agricultural Development. Available online: https://www.ifad.org/en/web/ operations/country/id/dominican_republic (accessed on 28 May 2020).

86. León, Y.M. The impact of tourism on rural livelihoods in the Dominican Republic's coastal areas. J. Dev. Stud. 2007, 43, 340-359. [CrossRef] 
87. Liu, A.; Wall, G. Planning tourism employment: A developing country perspective. Tour. Manag. 2006, 27, 159-170. [CrossRef]

88. Pencarelli, T.; Splendiani, S.; Fraboni, C. Enhancement of the "Blue Flag" Eco-label in Italy: An empirical analysis. Anatolia 2016, 27, 28-37. [CrossRef] 